УДК 631.153.3:327.39(477)

(C) 2013

Кузьменко О. Б., доктор економічних наук

Чорноморський державний університет ім. Петра Могили

\title{
ОРГАНІЧНЕ ЗЕМЛЕРОБСТВО ЯК ФАКТОР ЄВРОІНТЕГРАЦІЇ УКРАЇНИ
}

\section{Рецензент - доктор економічних наук В. Г. В'юн}

\begin{abstract}
Обгрунтовано необхідність розвитку органічного землеробства в Україні як умови зростання експорту аграрної продукиії в Свропейський Союз, щяо одночасно забезпечує збереження і відтворення якісних характеристик земельних ресурсів. Доведено, щзо тендениії попиту на органічну продукиію в Свропейському Союзі та наявні якісні й екологічно чисті земельні ресурси в Украӥні створюють передумови для активізаиії органічного виробництва і відповідного експорту. Визначено проблеми,

щчо стримують впровадження даної системи землеробства, та пропозииії щзодо їх розв'язання.
\end{abstract}

Ключові слова: органічне землеробство, експорт, продукиія, Свропейський Союз, земельні ресурси.

Постановка проблеми. Аграрний сектор економіки України демонструє стабільні тенденції зростання (індекс обсягу сільськогосподарського виробництва за 2011 рік зріс на 17,5 \%) в умовах нестабільної світової фінансово-економічної ситуації. За цих умов активно розвивається експортний потенціал галузі. В 2012 році частка експорту в загальному обсязі зовнішньої торгівлі продукції аграрного сектора становила 69,8 \% і досягла 18,2 млрд дол. США [13].

Експорт сільськогосподарської продукції України в Свропейський Союз постійно зростає: 2010 рік - 2,12 млрд дол. США (29 \% у загальному експорті); 2012 рік - 5,08 (27,9\%) і в регіональній структурі займає друге місце [13]. Проте в товарній структурі цього експорту переважають насіння і плоди олійних рослин - 33,16 \% (це, в основному, насіння соняшнику і рапсу), жири та олії тваринного або рослинного походження - 29,75 \% (це олія тих же самих культур), зернові культури 7,44 \% [4], що забезпечено відповідним зростанням виробництва.

Однак високі врожаї зернових і олійних культур останніх років (2011 р. - 37,0 ц/га зернові та зернобобові культури; 18,4 ц/га - соняшник, 17,3 ц/га - ріпак) досягнуті за рахунок природної потенційної родючості грунту та сприятливих кліматичних умов [12].

Під урожай 2011 року у середньому на гектар посіву було внесено 68 кг діючої речовини на гектар мінеральних добрив та 0,5 т/га органічних добрив, що не забезпечує бездефіцитний баланс гумусу $(-0,37$ т/га) i поживних речовин $(-117,7$ кг/га) [10].

Зростання виробництва експортноорієнтованих культур, насамперед соняшнику i ріпаку, ведеться за рахунок розширення посівних площ цих культур, що порушує науково обгрунтовані сівозміни. Так, наприклад, у структурі посівних площ Миколаївської області за останні роки соняшник займає 26-31\%, що означає повернення даної культури на одне й те ж поле через 3-4 роки. Ця культура в науково обгрунтованих сівозмінах завжди закінчує ротацію культур і після неї обов'язково поле залишалося під чорний пар, а термін їі повернення не менше, ніж сім років. Як просапна культура соняшник підвищує інтенсивність водної ерозіі: на схилах від 1 до 3 градусів втрати гумусу в чорноземах під його посівами досягають 1,3-1,4 т/га щорічно [2].

Враховуючи євроінтеграційні прагнення України, виникає проблема вдосконалення експортної структури аграрного сектора в країни ЄС на підставі системи землеробства, що забезпечувала б стабільний попит на продукцію за раціонального використання та охорони земельних ресурсів. Однією з таких систем є органічне землеробство.

Аналіз основних досліджень і публікацій, у яких започатковано розв'язання проблеми. Засновником концепції органічного землеробства вважають японського філософа Мокіші Окада (1882-1955 рр.). Вагомий внесок у іï розвиток зробили також німецький вчений Рудольф Штейнер (1924 р. - біодинамічне землеробство), французький Лемер Буше (1964 р. - біологічне землеробство), українські вчені Іван Овсінський, Алекс Подолінський. Над цією проблемою плідно працювали всесвітньо відомі вчені Т. С. Мальцев, Ф. Т. Моргун, М. К. Шикула та інші. Незважаючи на активну діяльність науковців, площі земель органічного землеробства становлять в Україні в 2011 році 0,65\% 
загальної площі сільськогосподарських угідь. Однією з причин цього є недостатньо розвинутий ринок, передусім експортної продукції.

Метою дослідження $\epsilon$ обгрунтування теоретичних засад органічного землеробства та надання практичних рекомендацій щодо його розвитку.

Досягнення поставленої мети зумовило необхідність вирішення наступних завдань:

- проаналізувати визначення сутності органічного землеробства;

- обгрунтувати необхідність розвитку даної системи землеробства для інтенсифікації експортного потенціалу аграрного виробництва України;

- окреслити перспективи розвитку органічного землеробства в Україні;

- встановити позитивний вплив органічних технологій на якісний стан грунтів;

- виявити стримуючі фактори розвитку органічного землеробства та запропонувати шляхи їх подолання.

Результати досліджень. Землеробство, як один із перших видів діяльності людства, тривалий час було спрямоване лише на збільшення виробництва продовольства та одержання сировини для промисловості. Такий підхід призвів до постійного зростання витрат енергії та ресурсів на виробництво одиниці продукції, а також до виснаження природного потенціалу грунтів i забруднення довкілля.

Для запобігання цих процесів було започатковано альтернативні системи землеробства (біологічне, органо-біологічне, біодинамічне, екологічне, органічне).

Основними елементами всіх цих систем землеробства $€$ :

- заборона або суттєве обмеження використання мінеральних добрив і пестицидів;

- підтримка родючості грунтів за рахунок внесення органічних добрив (гною, сидератів, рослинних решток, іншої органіки);

- мінімальний грунтозахисний обробіток грунту, що запобігає його деградації;

- д дотримання науково обгрунтованих сівозмін;

- біологічні засоби боротьби зі шкідниками;

- заборона використання генетичномодифікованих організмів.

За своєю сутністю об'єднання цих елементів i $\epsilon$ визначенням органічного землеробства, даним Департаментом сільського господарства США ще у 1980 році [17].

За визначенням Міжнародної федерації 3 розвитку органічного землеробства (IFOAM), органічне землеробство об'єднує всі сільськогосподарські системи, які підтримують екологічно-, соціально- та економічно доцільне виробництво сільськогосподарської продукції.

В основі таких систем лежить використання локально-специфічної родючості грунтів як ключового елементу успішного виробництва. Такі системи використовують природний потенціал рослин, тварин i ландшафтів i спрямовані на гармонізацію сільськогосподарської практики та навколишнього середовища.

Органічне землеробство суттєво зменшує використання зовнішніх факторів виробництва (ресурсів) шляхом обмеження застосування синтезованих хімічним шляхом добрив, пестицидів i фармпрепаратів. Замість цього для підвищення врожаїв та для захисту рослин використовуються інші агротехнологічні заходи й різноманітні природні чинники.

Органічне землеробство дотримується принципів, обумовлених місцевими соціальноекономічними, кліматичними та історикокультурними особливостями [16].

Зазначимо, що збереження та підвищення родючості грунтів $\epsilon$ одним із головних складових у системі органічного землеробства, на що i спрямовані основні технологічні прийоми та заходи.

Технології органічного землеробства стрімко поширюються в країнах Європейського Союзу (рис. 1).

Так, за період із 1985 по 2011 рік кількість органічних господарств у країнах ЄС зросла з 6058 до більше ніж 240000 , а площа земель органічного землеробства - зі 172 тис. га до 9,5 млн га, що становить 5,4 \% земель сільськогосподарського призначення.

Швидкими темпами зростає ринок органічних продуктів Свропейського Союзу (рис. 2) [14].

За період 2004-2011 років він зріс у 1,97 разу, досягнувши 19,7 млрд євро і маючи тенденції до подальшого зростання.

Найбільшими за обсягом $є$ ринки органічних продуктів таких країн як Німеччина (6,6 млрд євро), Франція (3,76 млрд євро), Велика Британія (1,9 млрд євро).

Найбільшим споживанням органічної продукції на душу населення визначаються Швейцарія - 177,4 євро, Данія - 161,9 євро, Люксембург 134,3 євро. 


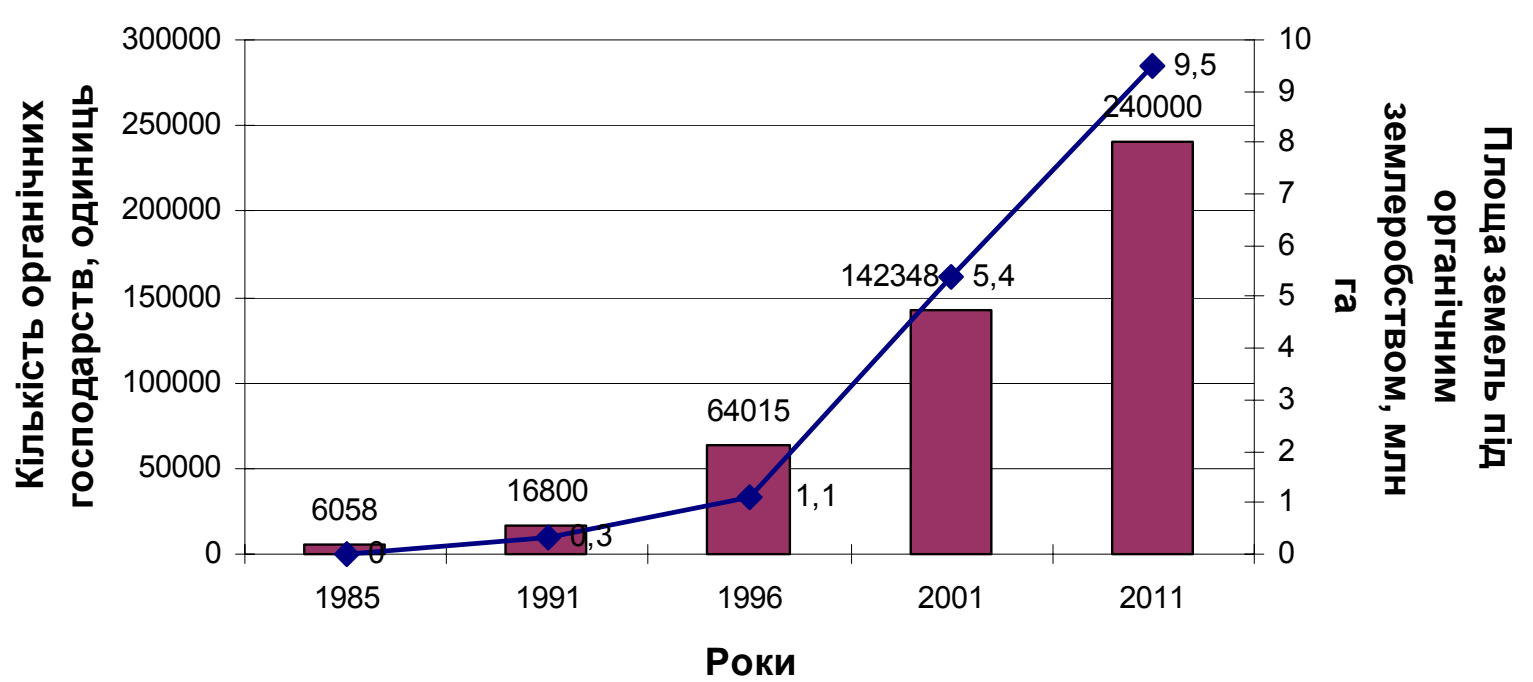

$\square$ кількість органічних господарств, одиниць

$\prec$ площа земель під органічним землеробством, млн га

Рис. 1. Динаміка кількості органічних господарств та площі земель під органічним землеробством у краӥнах Свропейського Союзу (побудовано за даними [15, 14])

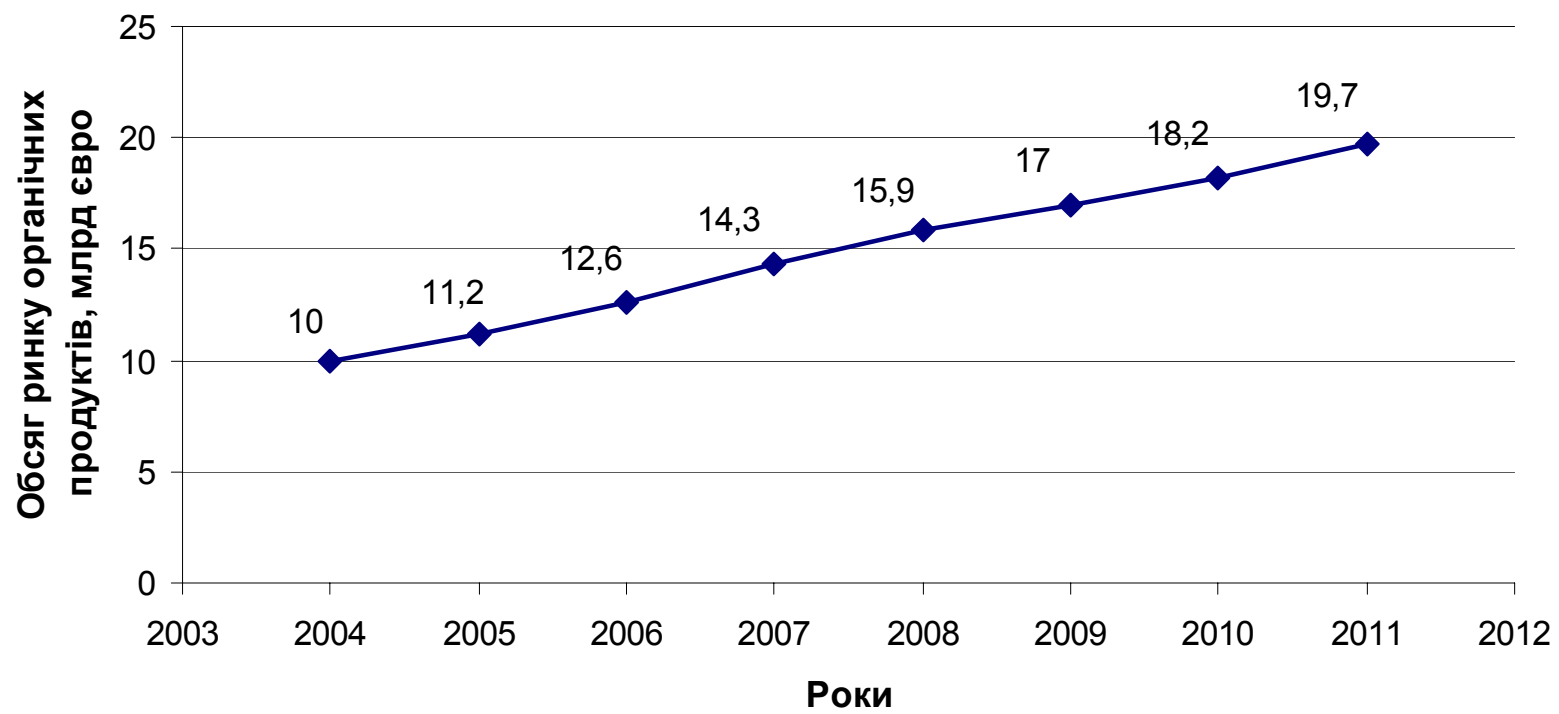

Рис. 2. Динаміка обсягу ринку органічних продуктів Свропейського Союзу (джсерело [14])

Основними мотивами споживання органічної продукції $є$ :

- екологічна безпека харчування, висока якість та свіжість продуктів;

- вищі смакові якості органічної продукції;

- збереження природного середовища у процесі виробництва;

- відсутність генетично модифікованих організмів.

Проте, не зважаючи на активний розвиток органічної продукції, Європейський Союз має обмежені можливості у розвитку даного виробництва.
Основні причини цього: низькі якісні характеристики грунтів та широке використання в сільському господарстві інтенсивних технологій.

Відведені під них території «оточують» землі органічних господарств, стримуючи їхній розвиток.

Враховуючи цю ситуацію й тенденції розвитку кон'юнктури ринку органічних продуктів Європейського Союзу Україна має перспективи зайняти на ньому свій сегмент.

Враховуючи євроінтеграційні прагнення України - особливо при створенні зони вільної торгівлі - органічне землеробство може стати 
одним iз факторів посилення економічних зв'язків із Свропейським Союзом $з$ одночасним впровадженням ресурсоощадних технологій.

В СС підтримується стабільний попит на органічне зерно, бобові, фрукти, овочі та продукти їх переробки.

Водночас у структурі експорту України в Європейський Союз вони займають незначну частку: зернові культури - 7,44 \%, їстівні плоди й горіхи $-3,53 \%$, овочі та коренеплоди - 1,1\% [4].

Наявність родючих, екологічно чистих земель і порівняно низька вартість робочої сили відкривають значні потенційні можливості активізації експортної діяльності.

За даними М. К. Шикули [11], в Україні $є$ близько восьми мільйонів гектарів екологічно чистих чорноземів. Кисиль В. І. виділяє зони, придатні для вирощування екологічно-чистої продукції [3], за якими близько 50 \% території Миколаївської і $80 \%$ Херсонської областей придатні для органічного землеробства.

Проте, за даними IFOAM, в Україні в 2011 р. під органічним землеробством було зайнято лише 270320 га у 155 сертифікованих господарствах [14].

Органічне землеробство підвищує екологоекономічну ефективність виробництва.

Дослідженням органічних технологій використання нетоварної продукції зернових культур iз супутньою обробкою мікробіологічними препаратами на типовому грунті Миколаївської області встановлено прискорення відновлення в ньому поживних речовин, органічної речовини, мікроелементного складу грунту, очищення грунту від важких металів [5-8].

Це дає змогу зекономити на застосуванні мінеральних добрив i отримувати додаткову продукцію [9].

Однак, не зважаючи на перспективи розвитку експортного потенціалу і збереження та відновлення якісних характеристик грунтів, стримуючими факторами розвитку органічного землеробства в Україні є:

1. Відсутність законодавчої бази у вигляді Закону України «Про виробництво та обіг органічної сільськогосподарської продукції та сировини», прийнятого Верховною Радою України в цілому 18.09.2012, що за пропозиціями президента України знаходиться на доопрацюванні.

2. Перехід до органічного землеробства триває від 2 до 5 років, протягом яких підприємець несе збитки від зниження урожайності та боротьби з бур'янами й шкідниками.

3. Платня за сертифікацію в ЄС становить 250-750 євро за середньої площі 30-50 га. В Україні середня площа сертифікованого господарства 2200 га, що збільшує витрати, а крім того треба оплатити транспорт і перебування інспектора [11].

4. Низький рівень інформованості, екологічної культури, освіти та інноваційної активності аграрних виробників.

Таким чином, для активізації експортного потенціалу i розв'язання екологічних проблем землеробства в Україні доцільно:

- розвивати законодавчу базу,

- забезпечити державну підтримку господарств у перехідний період та в ході проведення сертифікації на відповідність органічному виробництву,

- створити інфраструктуру ринку органічних продуктів.

Висновок. Експорт аграрної продукції України в СС в останній період демонструє стабільні темпи зростання, проте його товарна структура відрізняється значною часткою технічних культур і продуктів їх переробки.

Такий однобічний експорт продукції сприяє порушенню сівозмін і деградації земельних ресурсів.

Органічне землеробство в Свропейському Союзі має тенденції зростання за кількістю господарств, площі угідь і обсягу продукції, що споживається.

Враховуючи наявність великих площ родючих і екологічно чистих грунтів - в умовах зростання попиту на органічну продукцію в Свропейському Союзі - Україна має перспективи розвитку експортного потенціалу, посилення економічних зв'язків з ЄС за одночасного використання технологій, що сприяють збереженню i відновленню якісних характеристик грунтів.

Для цього потрібно:

- доопрацювати Закон України «Про виробництво та обіг органічної сільськогосподарської продукції та сировини»;

- надавати державну допомогу господарствам під час переходу на органічні технології та проведення сертифікації;

- активізувати інформаційно-консультаційну роботу із впровадження системи органічного землеробства. 


\section{БІБЛІОГРАФІЯ}

1. Відтворення родючості грунтів у грунтозахисному землеробстві / Під ред. М. К. Шикули - К. : Оранта, 1998. - 680 с.

2. Зубець M. Наші чорноземи - неоціненне надбання природи / М. Зубець, С. Балюк, Б. Носко // Голос України. - 2009. - №59(4559). - 2 квітня. C. $18-19$.

3. Кисиль В. I. Біологічне землеробство в Україні: проблеми і перспективи / В. І. Кисиль. - Харків : Штрих, 2000. - $161 \mathrm{c.}$

4. Клименко I. В. Спільна аграрна політика Європейського Союзу: можливості та виклики для України (аналітична доповідь) / I. В. Клименко, Н. Г. Бугрій, І. В. Ус. - К. : НІСД, 2011. - 19 с.

5. Кузьменко О. Б. Вплив мікробіологічних препаратів серії ЕМ на вміст важких металів у грунті при внесенні рослинних поверхневих решток зернових культур / О. Б. Кузьменко // Вісник Харківського національного університету ім. В. В. Докучаєва: Харків: вид-во ХНАУ, 2010. - №5. C. 202-206.

6. Кузьменко О. Б. Вплив мікробіологічних препаратів серії ЕМ на розкладання нетоварної частини урожаю зернових культур для повернення поживних речовин в грунт / О. Б. Кузьменко // Таврійський науковий вісник: [науковий журнал]. - Вип. 71. - Херсон, 2010. - С. 123-129.

7. Кузьменко О. Б. Вплив мікробіологічних препаратів серії ЕМ на розкладання нетоварної частини урожаю зернових культур для відновлення поживних речовин грунту / О. Б. Кузьменко // Вісник аграрної науки Причорномор'я : Науково-теоретичний фаховий журнал Миколаївського державного аграрного університету. - Вип. 2 (53). - Миколаїв: вид-во МДАУ, 2010. - С. 198 205.

8. Кузьменко О. Б. Вплив мікробіологічних препаратів серії ЕM на розкладання нетоварної час- тини урожаю зернових культур для відновлення мікроелементного складу грунту / О.Б.Кузьменко // Вісник Полтавської державної аграрної академії. - №3, 2010. - С. 44-49.

9. Кузьменко О. Б. Розвиток органічного землеробства в умовах ринку землі в Україні / О. Б. Кузьменко // Економіст: 2013. - №3. C. 38-39.

10. Національна доповідь про стан навколишнього природного середовища в Україні у 2011 році. - К. : Міністерство екології та природних ресурсів України, LAT\&K. - 2012. - 258 с.

11. Правила для виробників сертифікованої органічної продукції. [Електронний ресурс] Режим доступу: www.organic.com.ua

12. Сільське господарство України за 2011 рік / [ред. Н. С. Власенко]. - Державна служба статистики України. - ДП «Інформаційно-аналітичне агенство». - К., 2012. - $376 \mathrm{c.}$

13. Стан зовнішньоекономічних відносин у системі агропромислового комплексу України за 2012 рік. [Електронний ресурс]: за даними митних органів. - Режим доступу: min-agro.gov. ua/system/files/

14. FIBL and IFOAM. The World of Organic Agriculture Statistics and Emerging Trends 2013. [Електронний ресурс]. - Режим доступу: orgprints.org /22349/7/fibl-ifoam-2013-regions-2011.pdf.

15. M. Yussefi and H. Willer. The World of Organic Agriculture 2003: Statistics and Future Prospects. [Електронний ресурс]. - Режим доступу: www.ifoam.org

16. Organic Agriculture and Food Security (IFOAM Dossier 1, 2002) [Електронний ресурс]. - Режим доступу: www.ifoam.org

17. Report and Recommendations on Organic Farming (Washington DC: USDA, 1980), p. xii. NAL Call \# aS605.5U52 